\title{
Simulation of Ground-Water Flow and Areas Contributing Ground Water to Production Wells, Cadillac, Michigan
}

By C.J. Hoard and D.B. Westjohn

Prepared in cooperation with the city of Cadillac, Michigan

Scientific Investigations Report 2004-5175

U.S. Department of the Interior

U.S. Geological Survey 


\title{
U.S. Department of the Interior \\ Gale A. Norton, Secretary \\ U.S. Geological Survey \\ Charles G. Groat, Director
}

U.S. Geological Survey, Reston, Virginia: 2005

For sale by U.S. Geological Survey, Information Services
Box 25286, Denver Federal Center
Denver, CO 80225
For more information about the USGS and its products:
Telephone: 1-888-ASK-USGS
World Wide Web: http://www.usgs.gov/

\begin{abstract}
Any use of trade, product, or firm names in this publication is for descriptive purposes only and does not imply endorsement by the U.S. Government.

Although this report is in the public domain, permission must be secured from the individual copyright owners to reproduce any copyrighted materials contained within this report.
\end{abstract}

Suggested citation:

Hoard, C.J., and Westjohn, D.B., 2005, Simulation of Ground-Water Flow and Areas Contributing Ground Water to Production Wells, Cadillac, Michigan: U.S. Geological Survey Scientific Investigations Report 2004-5175, 18 p. 


\section{Contents}

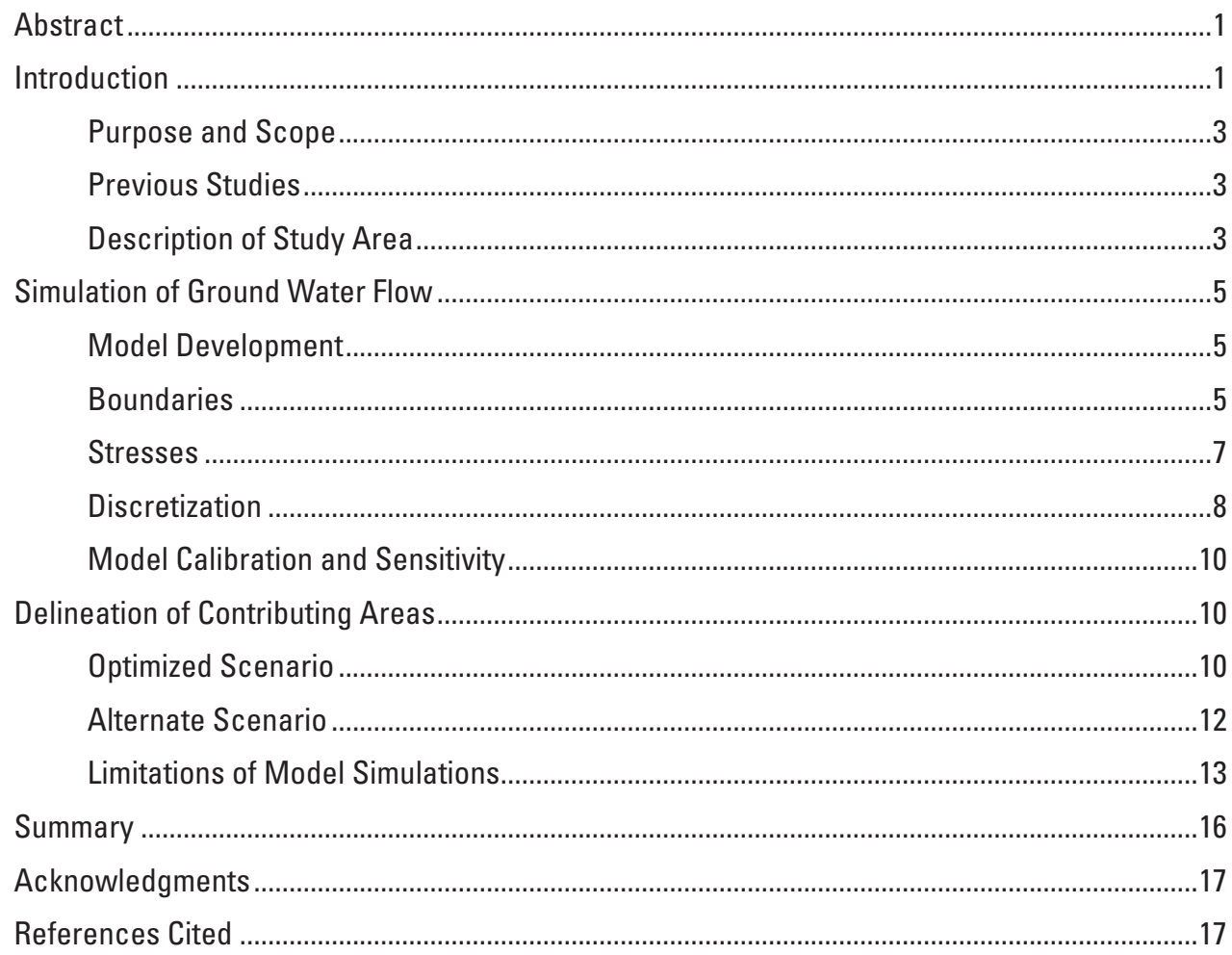

\section{Figures}

\section{1-3. Maps showing:}

1. Location of the Clam River watershed, Wexford and Missaukee Counties, Michigan.

2. Altitude of land surface and spatial distribution of estimated effective recharge (modified from Holtschlag, 1996) in the Clam River watershed, Michigan. .......................4

3. Surficial glacial deposits in the Clam River watershed, Michigan...................................

4. Hydrogeologic section from West to East through the Cadillac well field, Cadillac, Michigan.

5-6. Maps showing:

5. Potentiometric surface map for the intermediate aquifers $(>1050 \mathrm{ft}$ above

NGVD 29), Clam River watershed, Michigan.

6. Potentiometric surface map for the deep aquifer (<1050 ft above NGVD 29),

Clam River watershed, Michigan...

7. Conceptual diagram of ground-water flow for the Clam River watershed,

Cadillac, Michigan.

8. Map showing lateral discretization and location of specified head boundaries for the ground-water flow model of the Clam River watershed, 
9. Graph showing observed and simulated heads (water levels) for the calibrated ground-water flow model of the Clam River watershed, Michigan.

10-13. Maps showing:

10. Distribution of head (water level) residual (difference between observed and simulated heads) for the calibrated flow model for the Clam River watershed, Cadillac, Michigan.

11. Model-simulated heads, and head residuals for observations in the deep aquifer (layer 4), Clam River watershed, Michigan.

12. Ten-year contributing area for scenario with optimized parameters, Cadillac municipal-well field, Cadillac, Michigan 15

13. Ten-year contributing area for scenario with alternate parameters, Cadillac municipal-well field, Cadillac, Michigan. .16

\section{Tables}

1. Results of selected aquifer tests in the aquifer units underlying the Clam River watershed, Michigan

2. Parameter values for optimized model and alternate model of the Clam River watershed, Michigan

\section{Conversion Factors and Abbreviations}

\begin{tabular}{|c|c|c|}
\hline Maltiply & $\mathrm{By}$ & To obtain \\
\hline & Length & \\
\hline inch (in.) & 2.54 & centimeter (cm) \\
\hline foot (ft) & 0.3048 & meter $(m)$ \\
\hline mile (mi) & 1.609 & kilometer $\{\mathrm{km}$ ) \\
\hline \multirow[t]{2}{*}{$\begin{array}{l}\text { squaze mile } \\
\left(\mathrm{mi}^{2}\right)\end{array}$} & $\begin{array}{l}\text { Area } \\
2.59\end{array}$ & $\begin{array}{l}\text { square kilometer } \\
\left(\mathrm{km}^{2}\right)\end{array}$ \\
\hline & Flow rate & \\
\hline $\begin{array}{l}\text { gallon per } \\
\text { mismute } \\
\text { (gal/min) }\end{array}$ & 0.06309 & $\begin{array}{l}\text { liter per second } \\
(\mathrm{L} / \mathrm{s})\end{array}$ \\
\hline \multirow[t]{2}{*}{$\begin{array}{l}\text { inch per year } \\
\text { (in/yr) }\end{array}$} & 25.4 & $\begin{array}{l}\text { millimeter per year } \\
(\mathrm{mm} / \mathrm{yr})\end{array}$ \\
\hline & Hydrausic conductivity & \\
\hline $\begin{array}{l}\text { foot per day } \\
\text { (ft/d) }\end{array}$ & 0.3048 & $\begin{array}{l}\text { meter per day } \\
\text { (mid) }\end{array}$ \\
\hline
\end{tabular}

$>$ and $<$ symbols indicate greater than or less than, respectively.

Vertical coordinate information is referenced to the National Geodetic Vertical Datum of 1929 (NGVD 29).

Horizontal coordinate information is referenced to the North American Datum of 1983 (NAD 83).

Altitude, as used in this report, refers to distance above the vertical datum. 


\title{
Simulation of Ground-Water Flow and Areas Contributing Ground Water to Production Wells, Cadillac, Michigan
}

\author{
By C.J. Hoard and D.B. Westjohn
}

\section{Abstract}

Ground water is the primary source of water for domestic, municipal, and industrial use within the northwest section of Michigan's Lower Peninsula. Because of the importance of this resource, numerous communities including the city of Cadillac in Wexford County, Michigan, have begun local wellhead protection programs. In these programs, communities protect their ground-water resources by identifying the areas that contribute water to production wells, identifying potential sources of contamination, and developing methods to cooperatively manage and minimize threats to the water supply.

The U.S. Geological Survey, in cooperation with the city of Cadillac, simulated regional ground-water flow and estimated areas contributing recharge and zones of transport to the production well field. Ground-water flow models for the Clam River watershed, in Wexford and Missaukee Counties, were developed using the U.S. Geological Survey modular three-dimensional finite-difference ground-water flow model (MODFLOW 2000). Ground-water flow models were calibrated using the observation, sensitivity, and parameter estimation packages of MODFLOW 2000. Ground-water-head solutions from calibrated flow models were used in conjunction with MODPATH, a particle-tracking program, to simulate regional ground-water flow and estimate areas contributing recharge and zones of transport to the Cadillac productionwell field for a 10-year period.

Model simulations match the conceptual model in that regional ground-water flow in the deep ground-water system is from southeast to northwest across the watershed. Areas contributing water were determined for the optimized parameter set and an alternate parameter set that included increased recharge and hydraulic conductivity values. Although substantially different hydrologic parameters (assumed to represent end-member ranges of realistic hydrologic parameters) were used in alternate numerical simulations, simulation results differ little in predictions of the size of the contributing area to the city well field. However, increasing recharge and hydraulic conductivity values appreciably affected the shape of the contributing area and zone of contribution of reacharge.
Simulation results indicate that the region immediately to the south and southeast of the well field is contributing water to the production wells. Detailed aquifer characterization would be needed to describe and simulate the heterogeneous glacial deposits in the watershed.

\section{Introduction}

About 46 percent of Michigan's population relies on ground water as a source of drinking water (Alley and others, 1999). In an effort to protect these and other groundwater resources, the U.S. Environmental Protection Agency (USEPA) passed amendments to the Safe Drinking Water Act in 1986. One of these amendments encourages states to implement wellhead protection programs (WHPP) (Legal Information Institute, 2004). The State of Michigan Department of Environmental Quality (MDEQ) oversees the State WHPP and provides guidelines on how to assess the vulnerability of ground-water resources used for municipal water supplies. In addition, the MDEQ reviews and approves plans to protect areas contributing recharge to wells from sources of ground-water contamination.

The city of Cadillac, in Wexford County, Michigan (fig. 1), is developing a wellhead protection plan for their production well field. As part of the WHPP, the contributing area needs to be delineated. The U.S. Geological Survey (USGS) entered into a cooperative agreement in 2000 with the city of Cadillac to simulate regional ground-water flow and estimate areas contributing recharge (areas on land surface that contribute water to wells) and zones-of-transport (areas in the subsurface that contribute water to wells) to the production well field. For this report, the term contributing area refers to both the area contributing recharge (surface) and the zoneof-transport (subsurface) contributing water to a well. Model simulations will provide a basis for management decisions concerning the ground-water resources of the Clam River watershed. 

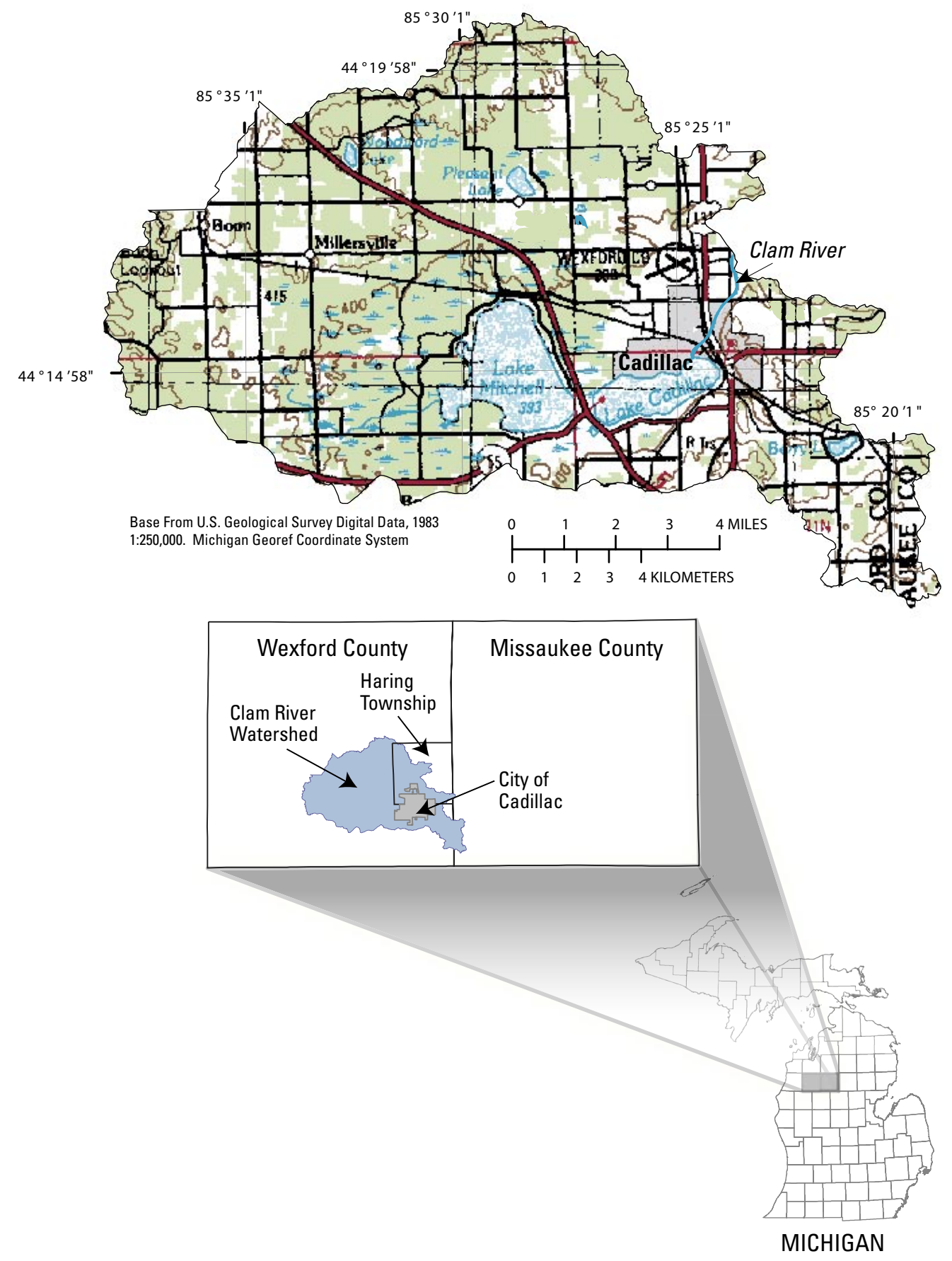

Figure 1. Location of the Clam River watershed, Wexford and Missaukee Counties, Michigan. 


\section{Purpose and Scope}

The purpose of this report is to describe the development and calibration of a regional ground-water flow model used in conjunction with a particle-tracking model to understand regional ground-water flow and estimate the Wellhead Protection Area (WHPA) for the city of Cadillac's production wells. This type of analysis assists waterresource managers in addressing concerns about protection and availability of their ground-water resources. In addition, this approach to identifying WHPA's can be applied in other areas of the State.

A conceptual model of the Clam River watershed was constructed on the basis of hydrogeologic data collected during this and previous investigations. A steady-state numerical model, developed on the basis of the conceptual model, was calibrated and optimized using MODFLOW 2000. A hypothetical scenario using high aquifer recharge rates and hydraulic-conductivity estimates was performed. The effect of different model parameters representing various characteristics of the ground-water system had on the resulting contributing area is also described.

\section{Previous Studies}

Before 1960, the city of Cadillac used Lake Cadillac (fig. 1) for their municipal water supply (Michigan State University Extension, 2002). Exploratory drilling indicated three sand and gravel aquifers termed the "shallow", "intermediate", and "deep" aquifers. Clay-confining units separate the aquifers. As part of the conversion to ground water for municipal use, aquifer tests were performed in the areas that became the city's well field. Jones, Henry and Williams Consulting Engineers (1959) performed the initial tests and concluded that the deep aquifer ( $>265$ feet below ground surface) was the best option for the city. Their evaluation of the data indicated that the deep aquifer had a high transmissivity (214 ft/d), was confined, and was likely protected from shallow sources of environmental contamination (Jones, Henry, and Williams Consulting Engineers, 1959). Keck Consulting Services (1987) evaluated the same aquifer test and estimated the volume of water leaking through the clay confining unit that overlies the deep aquifer. Results of the Keck analysis indicate that this clay confining unit is leaky and transmits about 4.2 percent of the water withdrawn from the well field, or as much as $103 \mathrm{gal} / \mathrm{min}$ (Keck Consulting Services, 1987). Aquifer-test information also is available for the production wells for Haring Township, which is just north of the city of Cadillac (fig. 1) (J.L. Wilcox \& Associates, 1986). These data indicate that the deep aquifer underlying Haring Township has hydraulic properties similar to those of the deep aquifer underlying Cadillac.

Cadillac placed their well field in the industrial park in an effort to minimize distance to the major water users (Michigan State University Extension, 2002). Contamina- tion by metals, and volatile organic compounds (VOC's) was discovered in water samples from the shallow aquifer near the well field as early as 1978 (E.C. Jordan Co., 1986). As a result, various hydrogeologic studies were done to describe the contaminant plumes and select remediation strategies to protect the well field. E.C. Jordan Co. (1986) was among the first organizations to study the relations among industrial park activities, water quality, and the hydrogeology of the area immediately around the well field. Investigations by WW Engineering and Science (1989a, 1989b, 1994), Environmental Science and Engineering Inc. (1996, 2000), QST Environmental (1998), and Roy F. Weston Inc. of Michigan (2001, 2002) provided additional information on aquifer characteristics, types of contaminant plumes and their migration paths, and the treatment strategies used to remediate the shallow aquifer.

Despite the large amount of hydrogeologic information available for the area near Cadillac's production well field, little hydrogeologic information was available for the greater Cadillac area. Leverett and Taylor (1915), as well as Stewart (1948), described the surficial geologic deposits of Wexford County. A geophysical study by Westjohn (1989) generated a subsurface geologic model of the area near Lake Mitchell (fig. 1). Additional work by Thomson (1969) describes the hydrology of the Manistee River system in various counties in northwestern Michigan, including Wexford County.

\section{Description of Study Area}

The study area is the Clam River watershed, which is in southeastern Wexford County and southwestern Missaukee County (fig. 1). Wexford County is in the northwestern portion of Michigan's Lower Peninsula (fig. 1), and the city of Cadillac is the county seat. Cadillac is the largest user of ground water in the area, largely because of the extensive base of industrial consumers of water resources. The Clam River watershed, which is part of the Muskegon River drainage system, is an area of about $96 \mathrm{mi}^{2}$. The total relief of the watershed area is approximately $350 \mathrm{ft}$, with topographic highs in the northwestern and southeastern portions of the watershed, and a topographic low near the center of the watershed (fig. 2). Surface-water drainage is toward the northeast and drains into the Clam River (fig. 1).

The prominent surface-water features in the Clam River watershed are Lakes Mitchell and Cadillac, near the center of the watershed (fig. 1). Lake Mitchell is the larger of the two lakes, with an area of approximately 4.15 $\mathrm{mi}^{2}$; the lake is about $22 \mathrm{ft}$ deep at its deepest point. Lake Cadillac is $1.83 \mathrm{mi}^{2}$ and is roughly $28 \mathrm{ft}$ deep at its deepest point (Frier, 1978). The lakes are joined by a canal that has effectively made the water levels of the two lakes the same. The Clam River is the only outlet for Lake Cadillac and drains to the northeast (fig. 1). A control structure on the Clam River maintains water levels in the lakes in the 


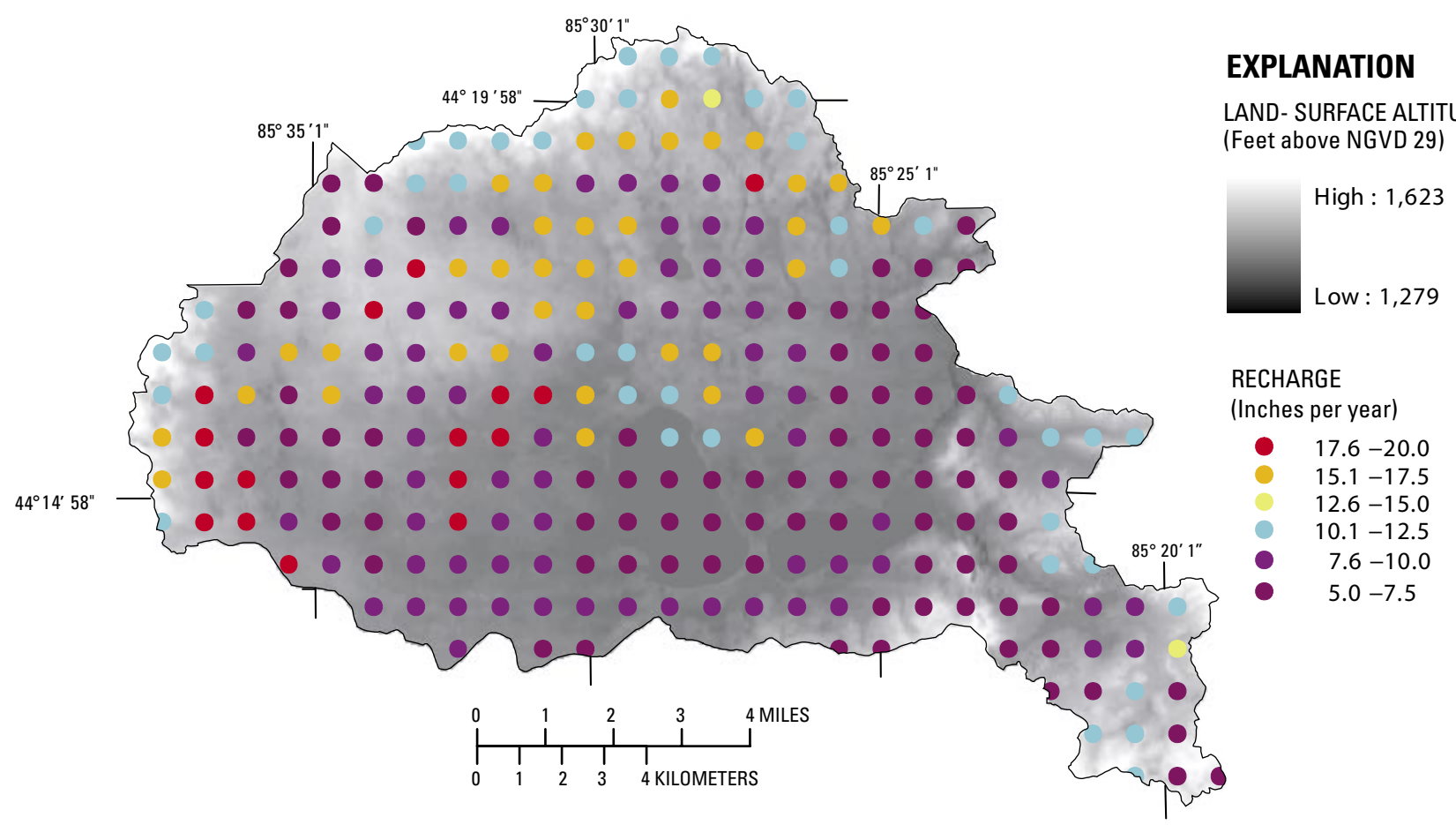

Figure 2. Altitude of land surface and spatial distribution of estimated effective recharge (modified from Holtschlag, 1996 in the Clam River watershed, Michigan.

range from 1,288.9 to 1,290.0 ft above NGVD 29, depending on the season (Michigan State University Extension, 2002). Various smaller lakes, all less than $0.2 \mathrm{mi}^{2}$, are also located in the watershed and include Woodward, Pleasant, Berry, and the Twin Lakes (fig. 1).

On average, the watershed receives 32.5 in of precipitation in a year (Midwest Climate Center, 2003). Of that precipitation, an average of $10 \mathrm{in} / \mathrm{yr}$ enters the ground-water system as effective recharge (Holtschlag, 1996). However, recharge in the area is not spatially uniform (fig. 2) (Holtschlag, 1996). The upland areas, which consist of coarse-grained glacial deposits, receive more recharge than the lowland areas, which consist of finer-grained glacial deposits.

The lithologic units that underlie the Clam River watershed include unconsolidated glacial material and bedrock. Cadillac and all other users of ground water in the study area rely on ground water withdrawn from sand-and-gravel deposits that are part of a thick sequence (from 600 to over $900 \mathrm{ft}$ ) of Pleistocene glacial deposits (Westjohn and others, 1994). Bedrock that underlies these glacial deposits consists principally of sandstone, shale, carbonate, and evaporites of Mississippian to Pennsylvanian age. However, there has been no need to use bedrock aquifers for water supply because the overlying glacial deposits predominantly are permeable sand and gravel, and these deposits provide the quantity and quality of ground water needed for industrial, commercial, and domestic use.

Maps of surficial deposits in Michigan (fig. 3) (Martin, 1955; Farrand and Bell, 1982) show the Clam River watershed coincides with an east-west trending oblateshaped area where glacial deposits consist of outwash sand and gravel. Maps by Martin (1955), and Farrand and Bell (1982) show a sequence of moraines surrounding the Clam River watershed (fig. 3). Many exposures of these mapped moraines were examined during the present study and it was determined that these exposures are composed of coarse sand and gravel.

One interpretation of the origin of these glacial deposits is that the area is part of an extensive sequence of stagnation-deglaciation deposits (using the nomenclature of Bates and Jackson, 1987) that formed by mass wasting of large, isolated ice blocks at the end of the Pleistocene Epoch. The Clam River watershed appears to be the former location of 


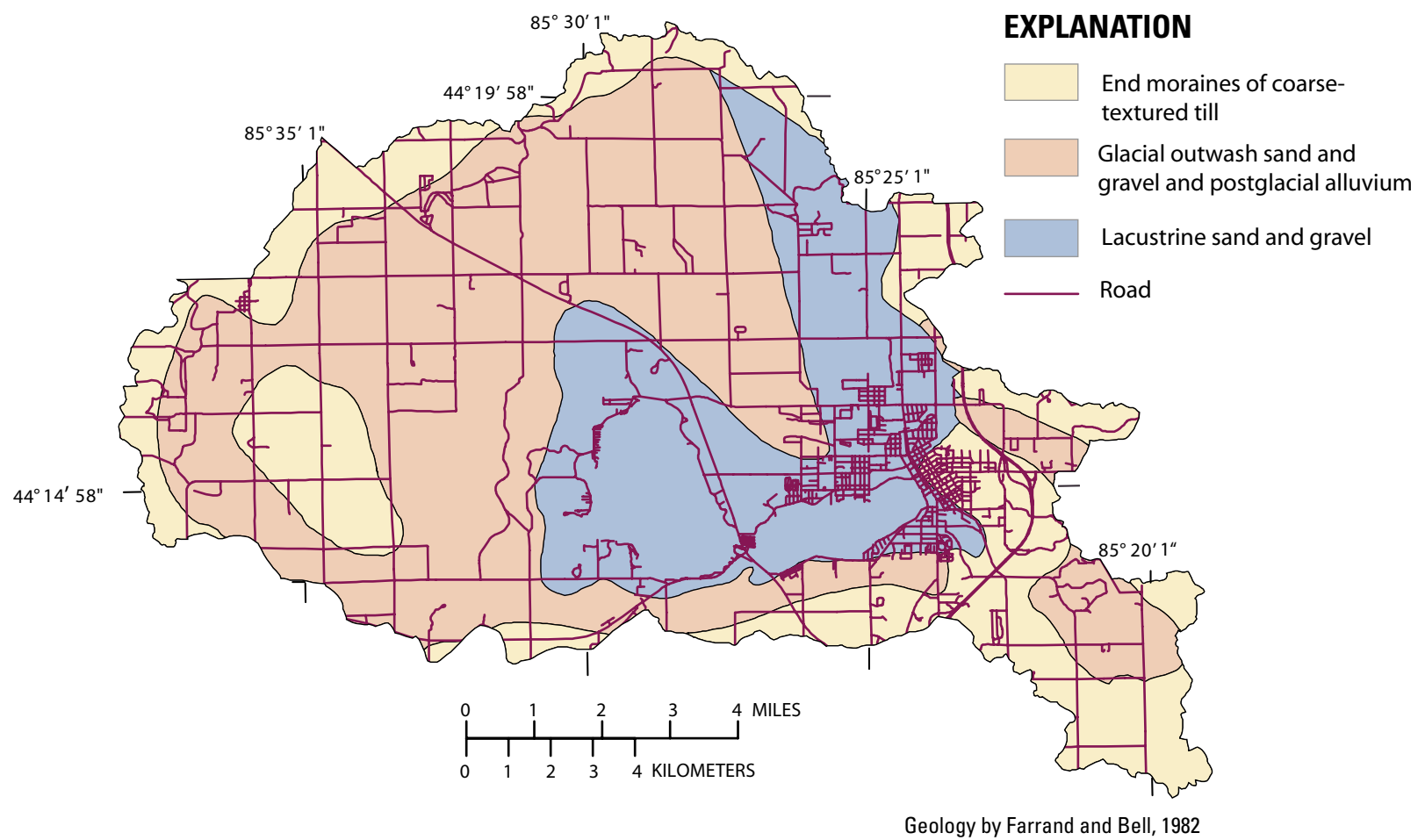

Figure 3. Surficial glacial deposits in the Clam River watershed, Michigan.

a massive ice block. Evidence from geophysical logs, geologic logs, and exposures of glacial sediment indicate that as this ice block down wasted during the end of the Pleistocene, outwash fans formed away from the large isolated ice mass. These outwash fans formed the ridges that surround the watershed. Lakes Cadillac, Mitchell, Woodward, Pleasant, and the extensive wetlands area that forms a large part of the watershed, likely mark the location of an extensive area where outwash deposits collapsed inward toward melting, buried ice blocks. A representative hydrogeologic section is shown in figure 4 , which illustrates the four primary aquifers and three primary confining units underlying the study area as considered in this study. For this study, the intermediate aquifer has been divided into two units ( 1 and 2 ). In general, the altitudes of occurrence of the aquifers are given below.

Shallow aquifer Intermediate aquifer 1 Intermediate aquifer 2 Deep aquifer

$1,300-1,278 \mathrm{ft}$ above NGVD 29 $1,273-1,139 \mathrm{ft}$ above NGVD 29 $1,135-1,073 \mathrm{ft}$ above NGVD 29 1,050 - $700 \mathrm{ft}$ above NGVD 29

\section{Simulation of Ground-Water Flow}

\section{Model Development}

The conceptual model of the Clam River watershed incorporates locations and effects of hydrologic boundaries, the general pattern of ground-water flow, sources and sinks of water, and the aquifers and confining units (fig. 4) in the Clam River watershed. Changes to the conceptual model can be made as more information is collected and the ground-water system is better understood. The sections below describe this conceptual model.

\section{Boundaries}

Ground-water system boundaries were chosen to coincide with the surface-water-drainage divide of the watershed. Along northern and southern portions of the study area, no-flow boundaries were used whereas specified-head (water level) boundaries were used along the northwestern 
A

Cadillac Well Field

$A^{\prime}$

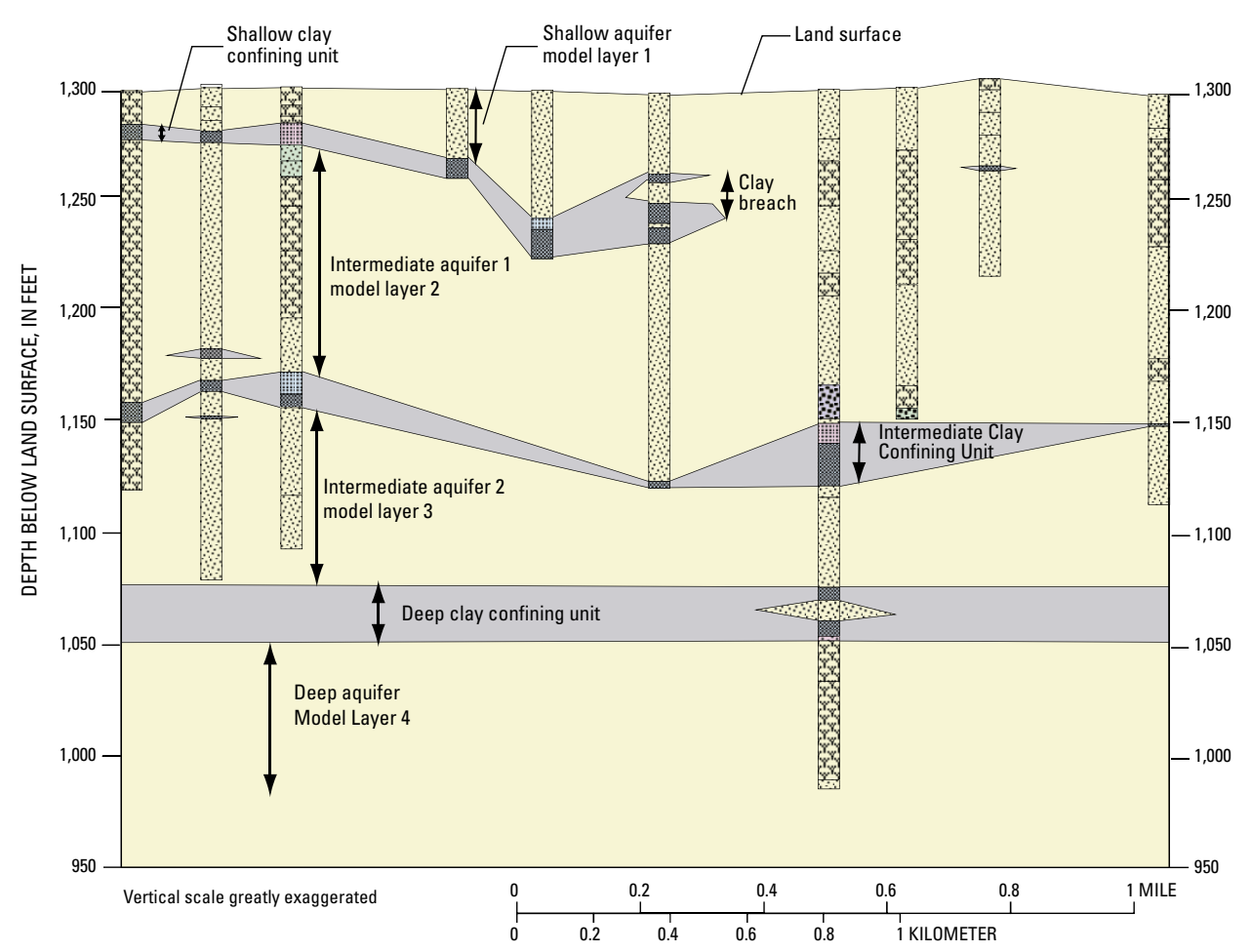

EXPLANATION

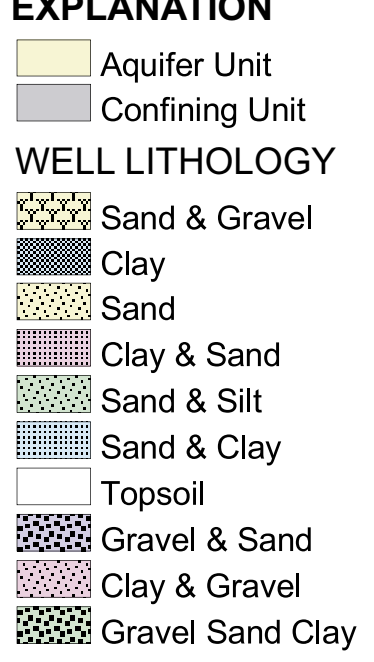

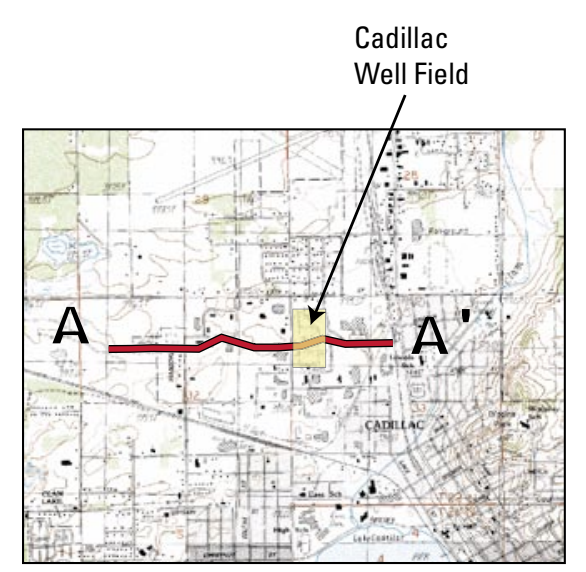

Figure 4. Hydrogeologic section from west to east through the Cadillac well field Cadillac, Michigan. 


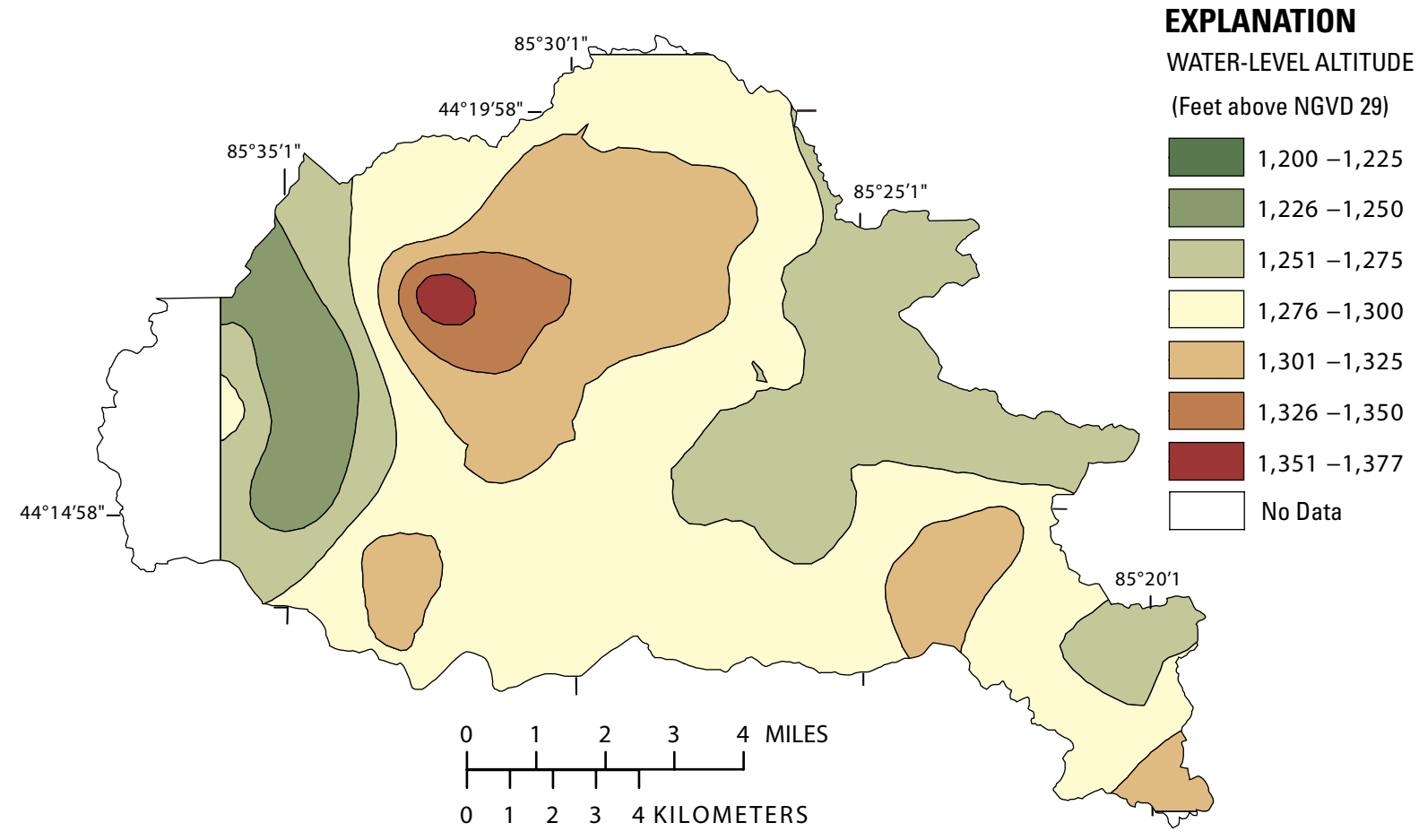

Figure 5. Potentiometric surface map for the intermediate aquifers (greater than $1050 \mathrm{ft}$ above NGVD 29), Clam River watershed, Michigan.

and southeastern boundaries. The specified head boundaries were assigned on the basis of potentiometric-surface maps generated from a combination of measured water levels and water levels reported on geologic logs. For the shallow and intermediate aquifers, ground-water flow is from the highlands in the northwest and southeast towards the lowlands in the center of the study area (figs. 2,5,7). However, the ground-water flow pattern in the deep aquifer reflects a regional trend in ground-water flow from the southeast toward the northwest (figs. 6,7). As a result, the specified head boundaries for the deep aquifer were assigned to match the potentiometric surface of the deep aquifer.

The top and bottom of the model are both treated as no-flow boundaries. Land-surface altitude was used for the top no-flow boundary. An altitude of $700 \mathrm{ft}$ was used for the bottom no-flow boundary; this was chosen arbitrarily because little is known about ground-water flow at that depth.

\section{Stresses}

Sources of water in the watershed include recharge from precipitation, surface-water features, and injection well discharge. Recharge was applied to the uppermost active model layer based on Holtschlag's (1996) estimates (fig. 2,7). The surface-water features were conceptualized as perched on low-permeability materials. Altitudes of lake surfaces from topographic maps were used to establish heads (water levels) for lakes in the study area. Riverhead stresses were assigned as $1 \mathrm{ft}$ lower than land-surface altitude based on the 30-meter digital elevation model. Permeability values from Calver (2001) were used to estimate bed-material conductance for lakes and rivers. Additional recharge was applied to the model to simulate an injection well used as part of a remediation system for contaminated ground water. Recharge from that well was approximately 200 gal/min (James Skipper, Michigan Department of Environmental Quality, oral commun., 2003). 


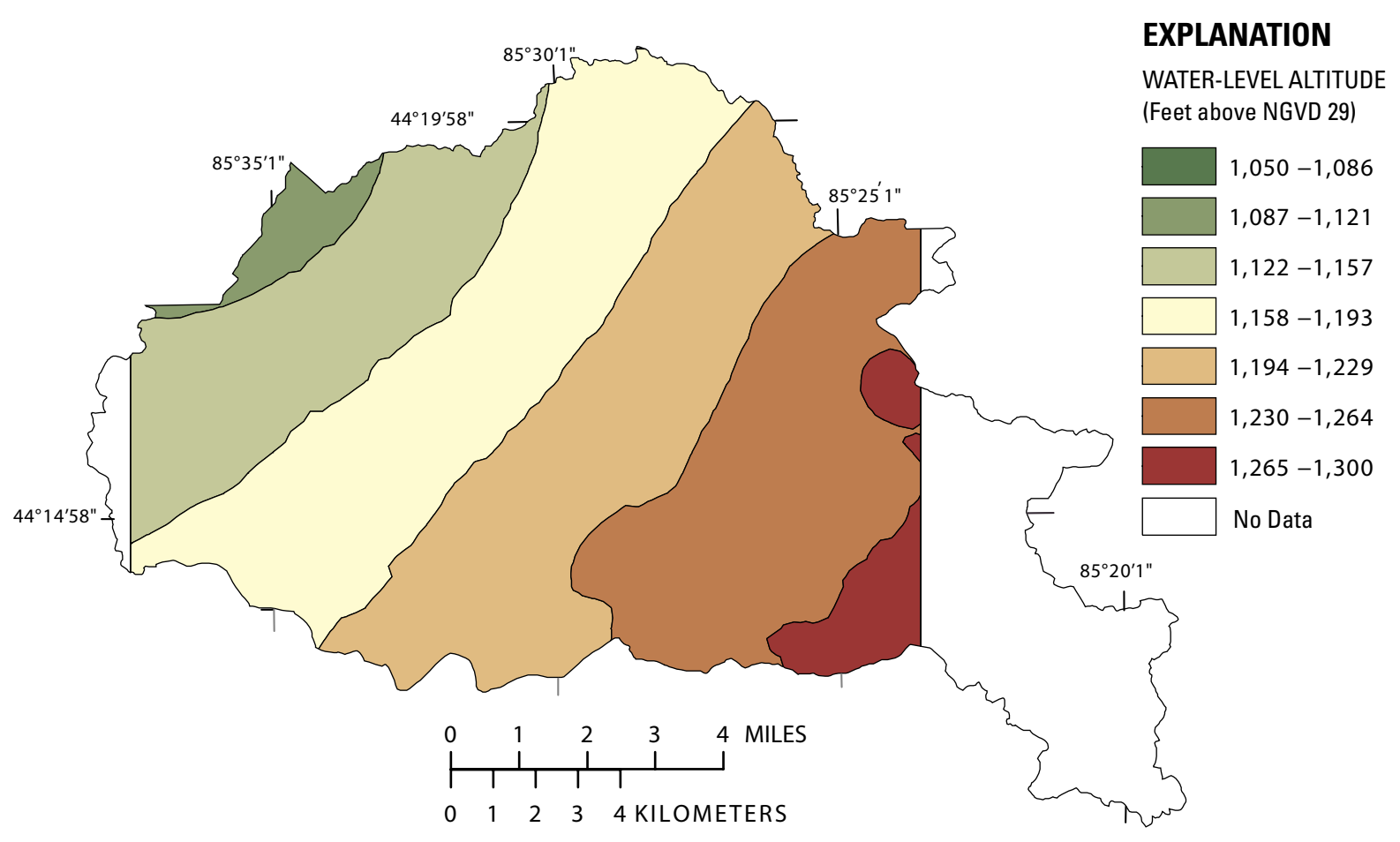

Figure 6. Potentiometric surface map for the deep aquifer (less than $1050 \mathrm{ft}$ above NGVD 29), Clam River watershed, Michigan.

Another major stress in the ground-water system was discharge from wells. Thirty-seven wells near the city of Cadillac were discharging water from the system at an approximate rate of $5116 \mathrm{gal} / \mathrm{min}$ during the model simulation (James Skipper, Michigan Department of Environmental Quality, oral commun., 2003; Larry Campbell, city of Cadillac, written commun., 2003; WW Engineering and Science, 1994). Twenty-nine of the wells were used as part of the remediation system in the industrial park near the Cadillac well field (fig. 4). Seven production wells were used by Haring Township and the city of Cadillac. The remaining well was used to supply cooling water for an energy cogeneration plant about $1 \mathrm{mi}$ west of the well field.

\section{Discretization}

Based on hydrogeologic descriptions recorded on well logs, geophysical logs of oil and gas wells, analysis of surface-geophysical surveys, and other information, the ground-water system underlying the Clam River watershed was divided into four model layers (fig. 4). The clay confining units were not modeled as separate layers but instead simulated the restriction of flow between aquifers. The layers corresponded to the aquifers described previously. Given the highly variable nature of the glacial deposits in this area, the continuity and extent of the various layers is difficult to delineate. In locations with a high density of water wells, the hydrogeology is better understood than in areas where well information is sparse. The layers are consistent with data from the well-field area. Hydraulic properties of these units estimated from aquifer tests are shown in table 1. A porosity of 30 percent (Freeze and Cherry, 1979) was used for all aquifers underlying the study area.

The numerical ground-water flow model was developed using the USGS modular three-dimensional finitedifference code MODFLOW 2000 (Harbaugh and others, 2000). All simulations reflect steady-state conditions, which indicate no net gain or loss of water in the system with time (storage effects are not simulated). As described above, the three clay confining units were not simulated as layers, but were simulated by including the confining-unit hydraulic conductivity and thickness in the calculation of vertical conductance between model layers (Harbaugh and 


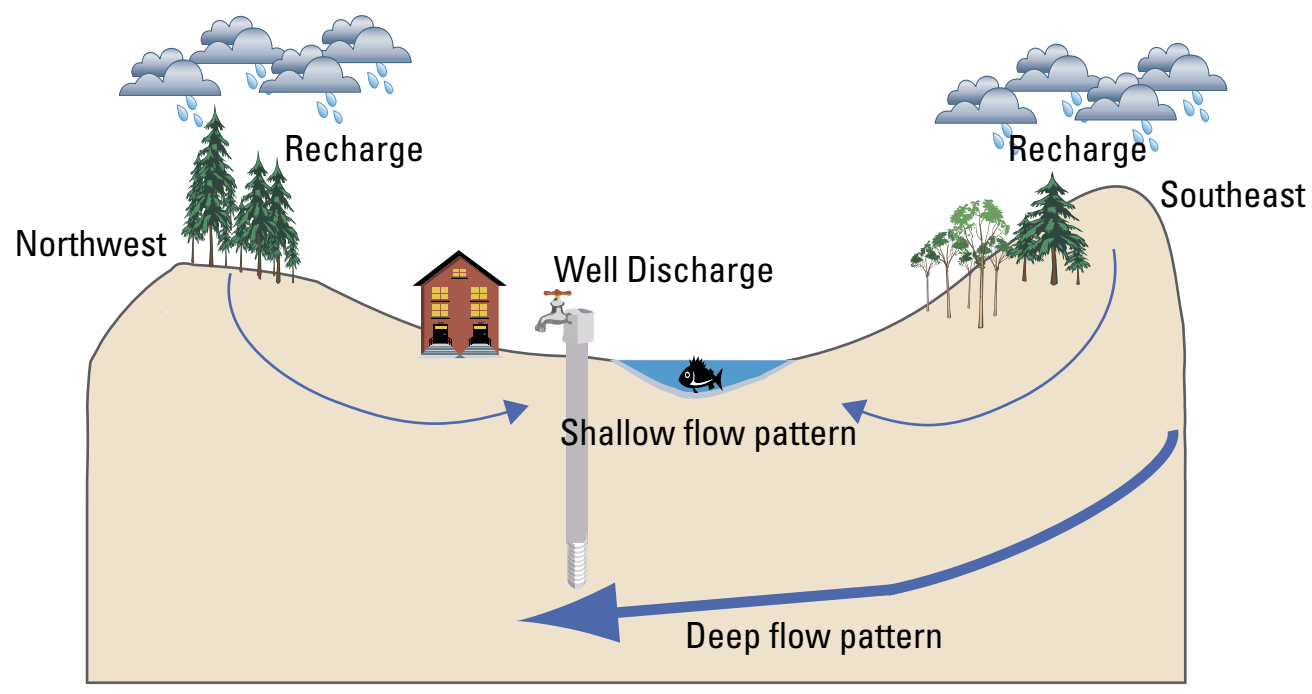

Figure 7. Conceptual diagram of ground-water flow for the Clam River watershed, Cadillac, Michigan.

Table 1. Results of selected aquifer tests in the aquifer units underlying the Clam River watershed, Michigan [ ft/d, feet per day]

\begin{tabular}{ccccc}
\hline Location & $\begin{array}{c}\text { Date of } \\
\text { test }\end{array}$ & $\begin{array}{c}\text { Screened Interval } \\
\text { (feet below ground } \\
\text { surface) }\end{array}$ & $\begin{array}{c}\text { Hydrologic Unit and Model } \\
\text { Layer }\end{array}$ & $\begin{array}{c}\text { Horizontal } \\
\text { Hydraulic } \\
\text { Conductivity }\end{array}$ \\
\hline Cadillac Industrial Park & 1996 & $20-35$ & Shallow aquifer, layer 1 & 129.6 \\
Cadillac Industrial Park & 1989 & $44-138$ & Intermediate aquifer, layer 2 & 74.0 \\
$\begin{array}{c}\text { South of Lake Cadillac } \\
\text { Cadillac Industrial Park }\end{array}$ & 1980 & $84-104$ & Intermediate aquifer, layer 2 & 43.9 \\
$\begin{array}{c}\text { Haring Township Well } \\
\text { Field }\end{array}$ & 1986 & $152-213$ & Intermediate aquifer, layer 3 & 163.0 \\
$\begin{array}{c}\text { Cadillac Municipal Well } \\
\text { Field }\end{array}$ & 1987 & $228-268$ & Deep aquifer, layer 4 & 109.5 \\
$\begin{array}{c}\text { Cadillac Municipal Well } \\
\text { Field }\end{array}$ & 1959 & $275-430$ & $\begin{array}{c}\text { Clay-confining unit between } \\
\text { intermediate and deep }\end{array}$ & 1.031 \\
\hline
\end{tabular}

${ }^{1}$ Denotes vertical hydraulic conductivity through the clay-confining unit 
others, 2000, p. 29-31). The presence of clay units indicated on well logs within glacial sediments in the Clam River watershed were compiled and arranged according to thickness and altitude. Top and bottom altitudes of the clay units were interpolated across the model grid using an inversedistance weighted algorithm to form the three separate clay confining units. For cases where the interpolated clay units were interpreted to be absent, a breach in the clay unit was simulated by increasing its simulated vertical hydraulic conductivity (fig. 4).

Areal recharge estimates for the model were incorporated using a multiplier array. A multiplier array (Harbaugh and others, 2000) was established throughout the grid based on recharge values estimated by Holtschlag (1996). A parameter representing recharge in the watershed then was linked to this multiplier array so that all recharge values in the multiplier array were multiplied by the new adjusted parameter value.

The study area was discretized into a finite-difference grid consisting of 546 rows, 584 columns, and 4 layers (fig. 8). Cell spacing of the model grid ranged from approximately $3 \mathrm{ft}$ to $1,000 \mathrm{ft}$. The cell spacing was refined in areas simulating large ground-water withdrawals to avoid numerical instability caused by the steep head (water-level) gradients resulting from withdrawals.

\section{Model Calibration and Sensitivity}

Model simulations were calibrated to water-level measurements in consultant reports, well logs, and to measurements made by the USGS, with assistance of the city of Cadillac Public Works Department. In all, 315 observation points were used within the observation package in MODFLOW 2000 (Hill and others, 2000). Simulations during and after model calibration indicate that the model is sensitive to changes in the horizontal hydraulic conductivity of the deep and intermediate aquifers, the vertical hydraulic conductivity of the deep confining unit, and recharge. The model was not as sensitive to changes in the hydraulic conductivity of the shallow aquifer, or to vertical hydraulic conductivities of the confining units separating the shallow and intermediate (model layers 1 and 2) and the two intermediate (model layers 2 and 3 ) aquifers, and the simulated breach in the clay confining units. Parameters with low sensitivity were not estimated during the process; instead, they were set to reasonable values based on literature sources. Sensitive parameters were adjusted, but parameters with low sensitivity were not adjusted. Recharge was set to 1.5 times the values estimated by Holtschlag (1996) (fig. 2), even though this parameter was considered sensitive. This condition resulted because the recharge rates were set unreasonably high during the parameter-estimation process. This process iteratively changed parameter values to minimize residuals between observed and simulated water levels at the observation points. Final model-calibrated parameter values are listed in table 2. A comparison of observed and simulated heads is provided in figure 9 .

The spatial distribution of head residuals (difference between the observed and simulated heads) for the calibrated model is given in figure 10. The mean absolute error for the calibrated model was $9.2 \mathrm{ft}$. Simulated heads agree well with the observed heads near the municipal-well field (north of Lake Cadillac) with a mean absolute error of $4.8 \mathrm{ft}$. However, head residuals are larger at observation wells outside of the well field, indicated by a mean absolute error of $15.2 \mathrm{ft}$. This large error likely is a result of poor characterization and the lack of hydrogeologic information in the watershed away from the well field. Despite the large head residual for observations distant from Cadillac's well field, the model can still be used as a predictive tool. The WHPA will be designated by the State of Michigan for the area surrounding the Cadillac production well field. Because error associated with head predictions in that area is low, the uncertainty in the WHPA delineation probably will be low as well. Model-simulated heads for layer 4, the deep aquifer, are shown in figure 11. The gradient matches the conceptual model of flow from the southeast to the northwest in the deep ground-water system. Simulated flows were reasonable between aquifers, into and out of model boundaries, and for rivers and lakes. The calibrated water budget is given below.

\begin{tabular}{|c|c|c|}
\hline \multicolumn{3}{|c|}{ All values in cubic feet per day } \\
\hline & IN & OUT \\
\hline Constant head boundaries & $24,989,855.3$ & $36,577,247.3$ \\
\hline Wells & $38,500.0$ & $984,823.6$ \\
\hline $\begin{array}{l}\text { General Head boundaries } \\
\text { (rivers and lakes) }\end{array}$ & $3,925,557.2$ & $232,879.0$ \\
\hline Recharge & $8,841,101.0$ & 0.0 \\
\hline Total & $37,795,013.5$ & $37,794,949.9$ \\
\hline
\end{tabular}

\section{Delineation of Contributing Areas}

\section{Optimized Scenario}

Following the development of a calibrated groundwater flow model, the particle-tracking program MODPATH (Pollock, 1994) was used to estimate the contributing area and zone of transport area to production wells. Essentially, particles are placed on the faces of each model cell that is simulating a production well. The particles follow an advective-flow field backward from the well, thereby indicating the zone-of-transport area (subsurface), and if tracked long enough, the contributing area (surface) to the well.

A total of 200 particles (40 at each well) were simulated in the optimized model to be released in the well field 


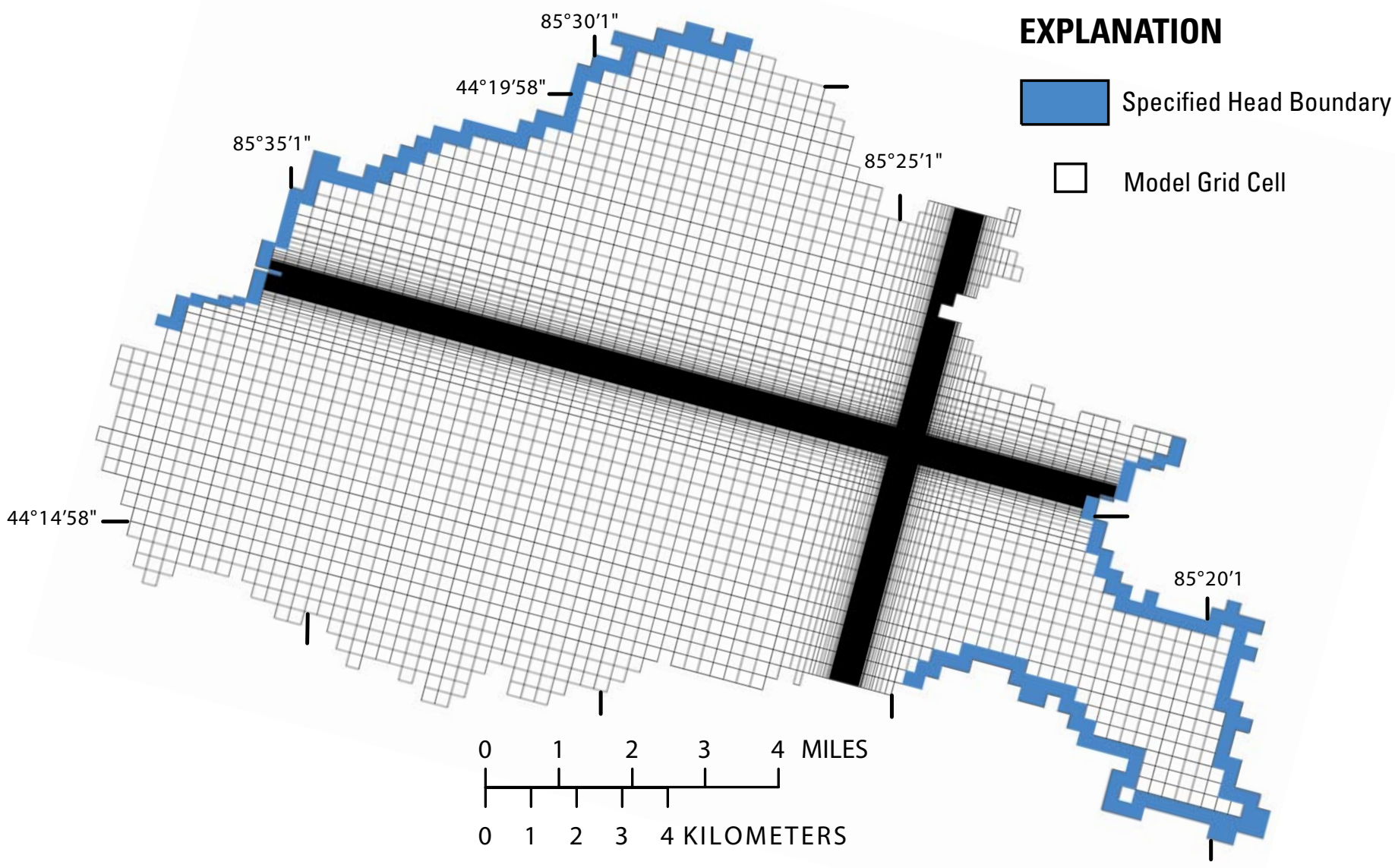

Figure 8. Lateral discretization and location of specified head boundaries for the ground-water flow model of the Clam River watershed, Cadillac, Michigan.

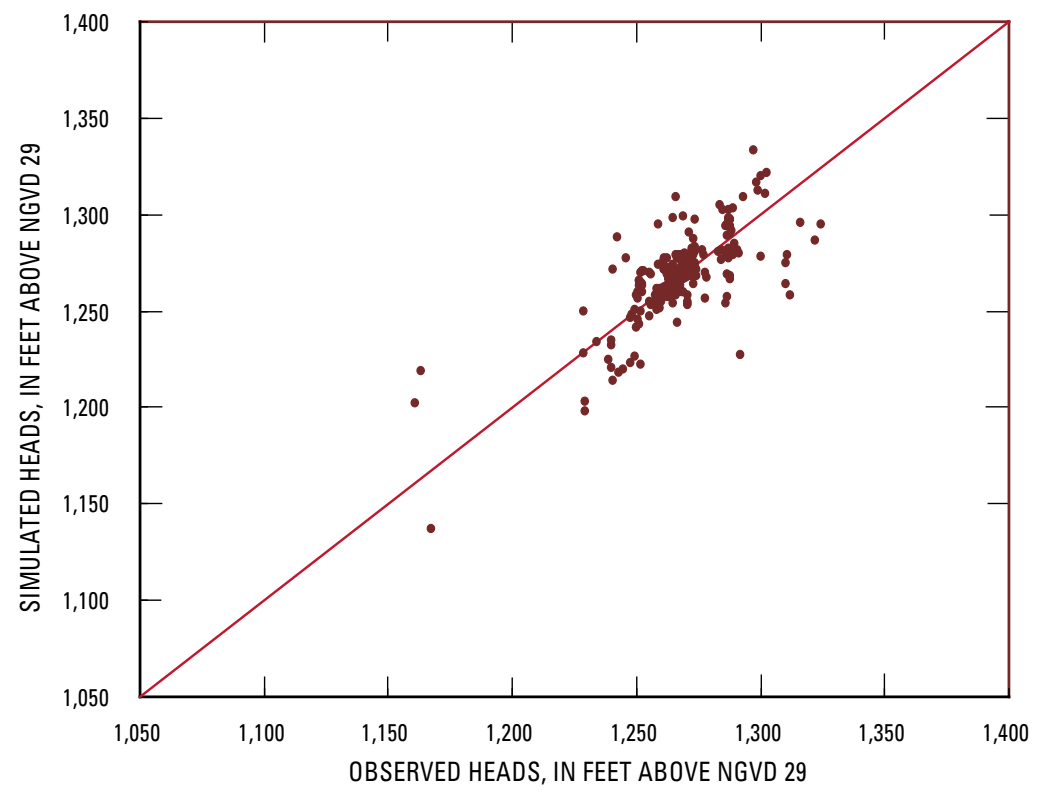

Figure 9. Observed and simulated heads (water levels) for the calibrated ground-water flow model of the Clam River watershed, Michigan. 


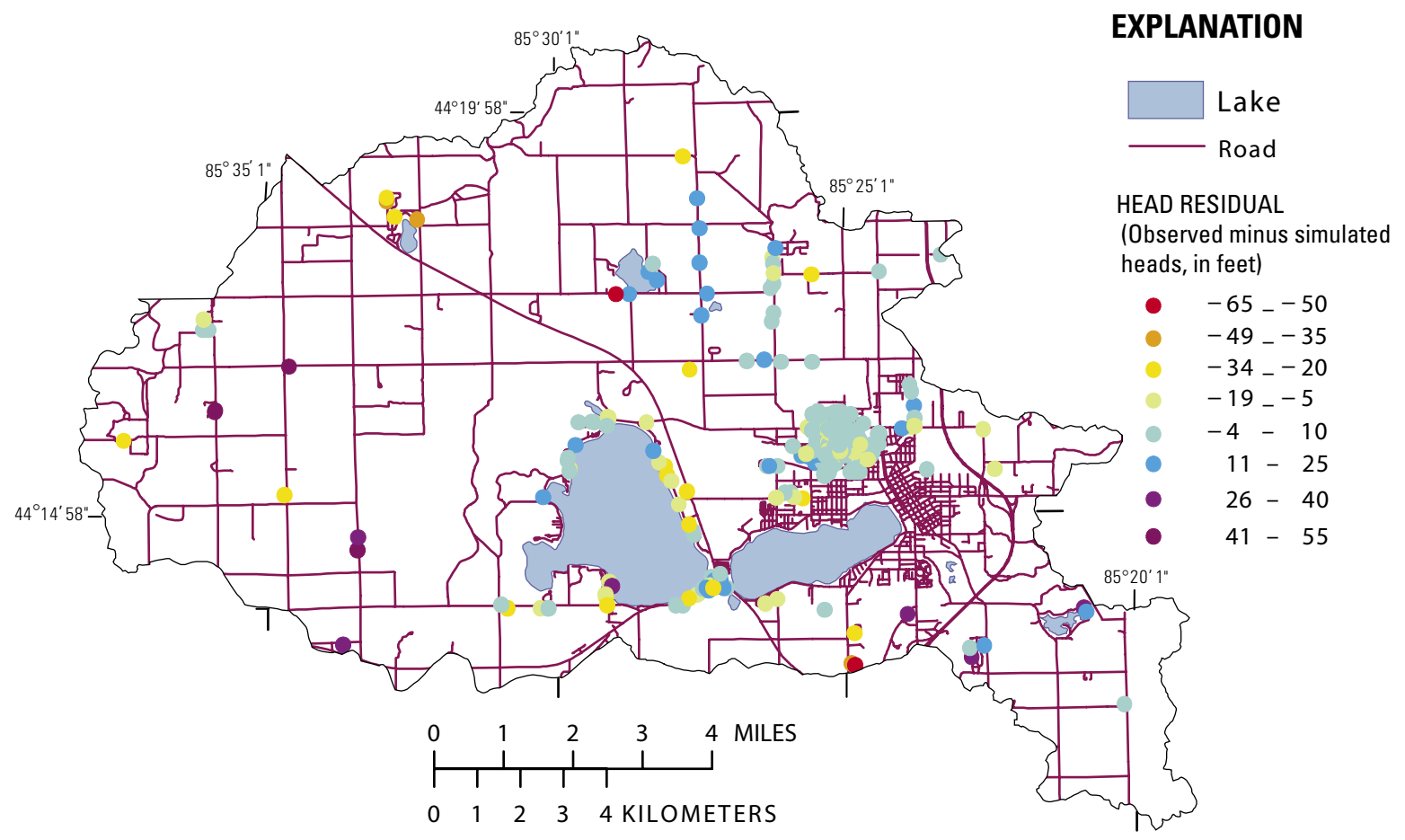

Figure 10. Distribution of head (water level) residual (difference between observed and simulated heads) for the calibrated flow model for the Clam River watershed, Cadillac, Michigan.

and tracked backwards from the Cadillac production wells. Particle movement was recorded at the end of a 10-year time period. The results of the backwards particle tracking are illustrated in figure 12. The resulting contributing area, shown in pink, is a map view of the composite simulated zone-of-transport and area contributing recharge. The 10year contributing area extends to the southwest and encompasses an area of $0.34 \mathrm{mi}^{2}$.

\section{Alternate Scenario}

A separate simulation was performed using a different set of values (other than the optimized values) for model parameters to test how sensitive the contributing area was to these changes. For this alternate scenario, the recharge rate was increased to $18 \mathrm{in} / \mathrm{yr}$ for the entire watershed. In addi- tion, the hydraulic conductivity values all were increased to near the upper limit of the values observed from the aquifer tests. The complete list of parameter values used for simulation of this alternate scenario is listed in table 2 . The pumping stresses also were changed to include a hypothetical production well. Well-discharge rates for the optimized scenario with five Cadillac production wells then were distributed evenly across the six production wells simulated in the alternate scenario. Forty particles were added around the hypothetical well for a total of 240 particles tracked during the simulation.

By changing values of model parameters, a more conservative estimate of the contributing area was provided in the alternate scenario. Despite the large increase in some model parameter values, the alternate contributing area is only slightly larger than the contributing area in the 


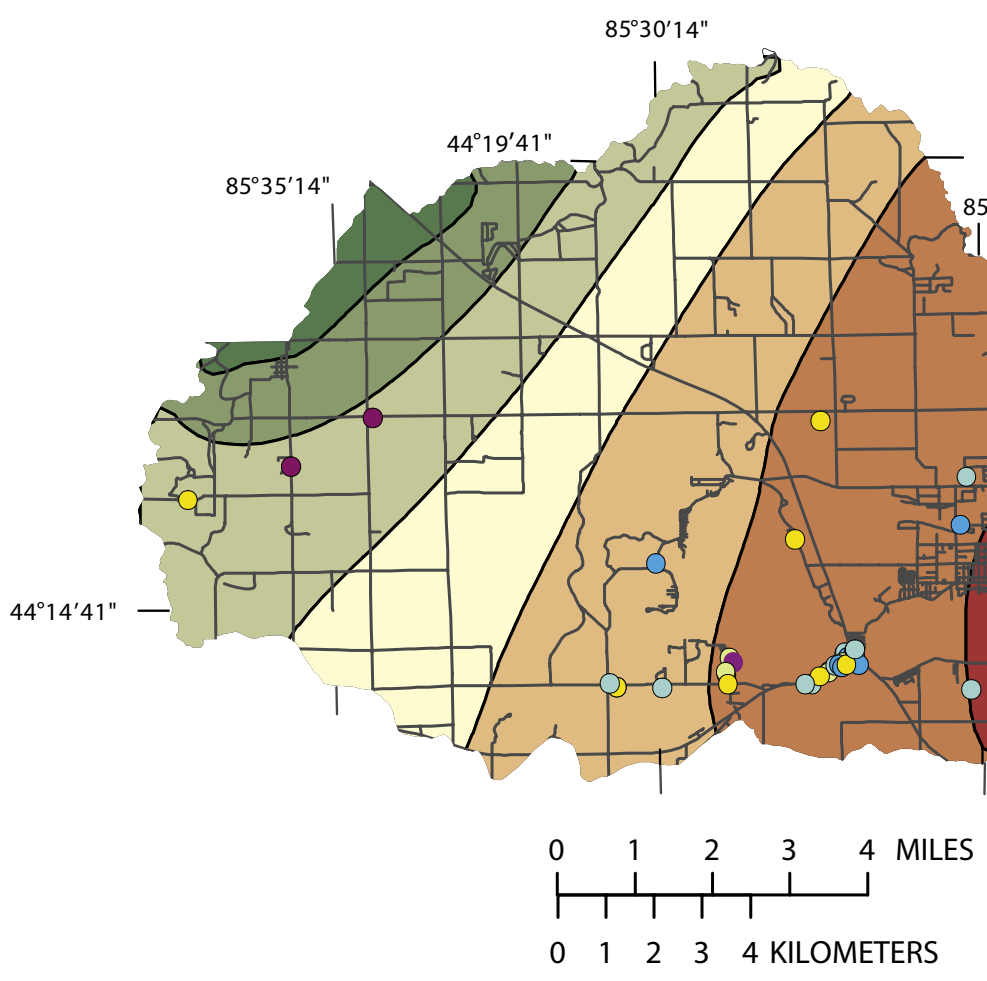

\section{EXPLANATION}

SIMULATED HEADS--Water level

(Feet above NGVD 29)

$1,097-1,124$

$1,125-1,150$

$1,151-1,177$

$1,178-1,203$

$1,204-1,230$

$1,231-1,256$

$1,257-1,283$

Roads

LAYER 4 HEAD RESIDUALS

(Observed minus simulated heads, in feet)
$-65--50$
$-49--35$
- $-34--20$
- $-19--5$
- $\quad-4 \quad-10$
- $11-25$
- $26-40$
- $41-55$

Figure 11. Model-simulated heads, and head residuals for observations in the deep aquifer (layer 4), Clam River watershed, Michigan.

optimized simulation. The result of increasing the model parameter values was to enlarge the contributing area from $0.34 \mathrm{mi}^{2}$ to $0.48 \mathrm{mi}^{2}$. The alternate contributing area (fig. 13 ) is narrower and extends further towards the south and southeast than the optimized contributing (fig. 12). The effect of simulating an additional production well also is apparent through the extension of the contributing area towards the northwest. In close proximity to the well field, the alternate contributing area does not extend as far south as the optimized contributing area. The narrowing of the alternate contributing area is likely because of the combination of the increased hydraulic conductivity of the aquifers and the decreased discharge rate per well in the alternate scenario simulation.

\section{Limitations of Model Simulations}

Uncertainty with simulated head predictions is a concern in all ground-water flow model simulations. The accuracy of the head solution is dependent on the data available concerning properties of hydrogeologic units, and location and effect of boundary conditions. In this model, each model layer was simulated as an isotropic unit, meaning that hydraulic properties were uniform in all directions. Although this isotropy probably is not the case for the aquifers represented with the model layers, data were not available at the scale needed to incorporate anisotropy for the simulated layers. A detailed aquifer characterization effort throughout the watershed would be necessary to characterize the heterogeneity associated with the glacial deposits in this area. The lack of detailed hydrogeologic 
Table 2. Parameter values for optimized model and alternate model of Clam River watershed, Michigan [in/yr, inches per year; ft/d, feet per day]

\begin{tabular}{|c|c|c|c|c|}
\hline Hydrologic unit and model layer & Parameter & $\begin{array}{c}\text { Value in } \\
\text { optimized model }\end{array}$ & $\begin{array}{l}\text { Value in } \\
\text { alternate } \\
\text { model }\end{array}$ & Units \\
\hline Shallow aquifer; layer 1 & Recharge & ${ }^{1} 1.50$ & 18 & $\mathrm{in} / \mathrm{yr}$ \\
\hline Shallow aquifer; layer 1 & $\begin{array}{l}\text { Horizontal hydraulic } \\
\text { conductivity }\end{array}$ & 51 & 120 & $\mathrm{ft} / \mathrm{d}$ \\
\hline $\begin{array}{l}\text { Confining unit between the shallow } \\
\text { and intermediate } 1 \text { aquifers; layers } 1 \\
\text { and } 2\end{array}$ & $\begin{array}{l}\text { Vertical hydraulic } \\
\text { conductivity }\end{array}$ & .03 & .03 & $\mathrm{ft} / \mathrm{d}$ \\
\hline $\begin{array}{l}\text { Breach in confining unit between the } \\
\text { shallow and intermediate } 1 \text { aquifers, } \\
\text { layers } 1 \text { and } 2\end{array}$ & $\begin{array}{l}\text { Vertical hydraulic } \\
\text { conductivity }\end{array}$ & 25 & 36 & $\mathrm{ft} / \mathrm{d}$ \\
\hline Intermediate aquifer 1 ; layer 2 & $\begin{array}{l}\text { Horizontal hydraulic } \\
\text { conductivity }\end{array}$ & 116 & 120 & $\mathrm{ft} / \mathrm{d}$ \\
\hline $\begin{array}{l}\text { Confining unit between the } \\
\text { intermediate } 1 \text { and intermediate } 2 \\
\text { aquifers; layers } 2 \text { and } 3\end{array}$ & $\begin{array}{l}\text { Vertical hydraulic } \\
\text { conductivity }\end{array}$ & .04 & .04 & $\mathrm{ft} / \mathrm{d}$ \\
\hline Intermediate aquifer 2 ; layer 3 & $\begin{array}{l}\text { Horizontal hydraulic } \\
\text { conductivity }\end{array}$ & 44 & 120 & $\mathrm{ft} / \mathrm{d}$ \\
\hline $\begin{array}{l}\text { Confining unit between the } \\
\text { intermediate } 2 \text { and deep aquifers; } \\
\text { layers } 3 \text { and } 4\end{array}$ & $\begin{array}{l}\text { Vertical hydraulic } \\
\text { conductivity }\end{array}$ & .01 & .01 & $\mathrm{ft} / \mathrm{d}$ \\
\hline Deep aquifer; layer 4 & $\begin{array}{l}\text { Horizontal hydraulic } \\
\text { conductivity }\end{array}$ & 201 & 278 & $\mathrm{ft} / \mathrm{d}$ \\
\hline
\end{tabular}

\footnotetext{
${ }^{1}$ Parameter value is a multiplier of values taken from Holtschlag, (1996); the average areal recharge rate for the present calibrated model is $15 \mathrm{in} / \mathrm{yr}$.
} 


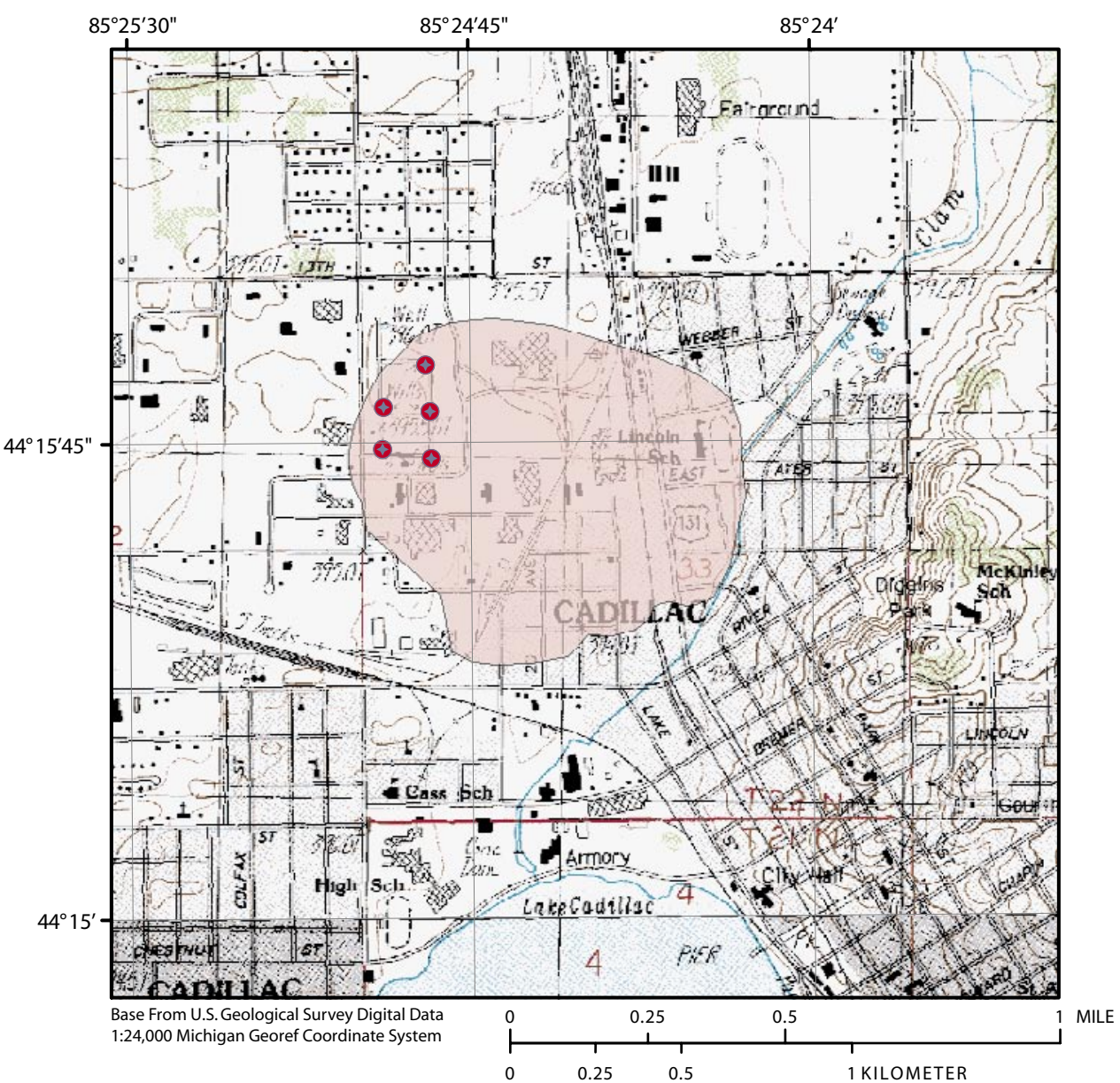

\section{EXPLANATION}

10-Year Contributing Area

Simulated Production Wells

Figure 12. Ten-year contributing area for scenario with optimized parameters, Cadillac municipal-well field, Cadillac, Michigan.

information in areas distant from the well field is indicated in the large head residuals in the observation wells in these areas (fig. 12).

Errors in head solutions translate to errors in the particle-tracking solutions because the numerical methods affect one another in model simulation. Reducing uncertainty in the ground-water flow solution also would improve the accuracy of the particle-tracking solution. In addition, the value used for porosity was not obtained by field measurements, so the estimated value of 30 percent may not be an accurate representation. If the effective porosity were smaller, then the contributing area would be larger because advective flow velocity increases with a decrease in porosity. 


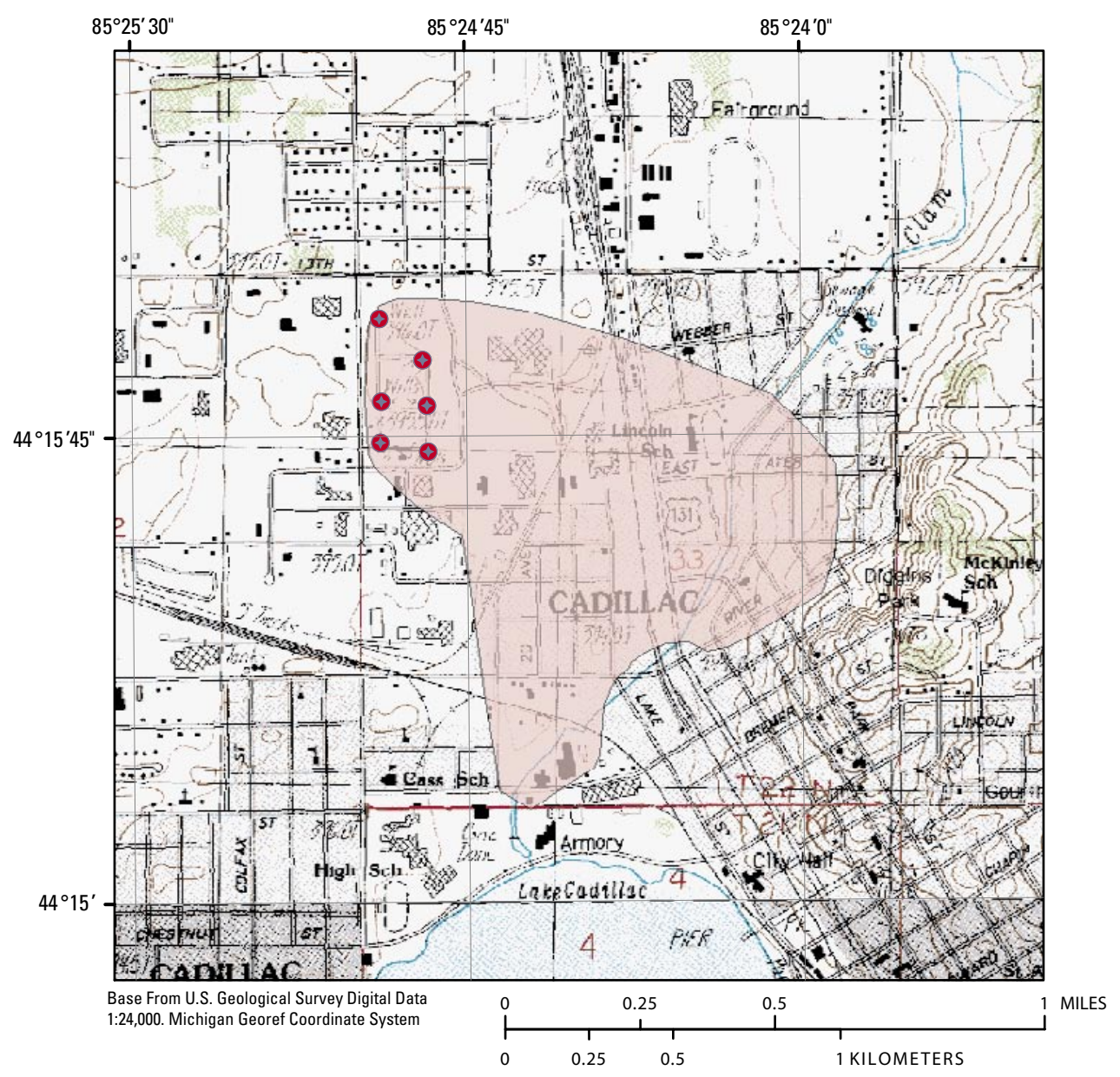

\section{EXPLANATION}

10-Year Contributing Area

Simulated Production Wells

Figure 13. Ten-year contributing area for scenario with alternate parameters, Cadillac municipal-well field, Cadillac, Michigan.

\section{Summary}

About 46 percent of Michigan's population relies on ground water as a source of drinking water. The city of Cadillac, in Wexford County, Michigan, is developing a wellhead protection plan for their production well field. To understand the regional ground-water resources and determine the surface and subsurface areas contributing flow to the production well field, the USGS, in cooperation with the city of Cadillac began a study in 2000. The study area (96 $\mathrm{mi}^{2}$ ) encompasses the Clam River watershed in southeastern Wexford County and part of southwestern Missaukee
County. The city of Cadillac is the largest user of ground water in the watershed. Total relief in the study area is approximately $350 \mathrm{ft}$. Surface-water drainage is toward the northeast through the Clam River. On average, the watershed receives $32.5 \mathrm{in} / \mathrm{yr}$ of precipitation, of which approximately $10 \mathrm{in} / \mathrm{yr}$ becomes ground water recharge. Unconsolidated glacial material and bedrock underlie the Clam River watershed. The watershed appears to be the former location of a massive ice block of glacial origin. Three aquifers termed the "shallow", "intermediate 1 and 2", and "deep" aquifers are separated by clay confining units within the glacial deposits. 
Ground-water flow simulations developed for the Clam River watershed using MODFLOW 2000 were used in conjunction with MODPATH to simulate regional groundwater flow and estimate areas that contribute ground water to the Cadillac production well field. Model simulations were calibrated to 315 water-level observation points. Head residuals between observed and simulated heads increased at observation points distant from the production well field. Simulations indicate that the model is most sensitive to recharge, the horizontal hydraulic conductivity of the deep and intermediate aquifers, and the vertical hydraulic conductivity of the deep confining unit. Model simulations match the conceptual model in that simulated regional ground-water flow in the deep ground-water system is from the southeast to northwest. The water budget for the calibrated model indicates reasonable flows between the aquifers and boundaries. Based on the results of groundwater-flow and particle-tracking simulations, the 10-year contributing area for the production wells extends southeast of the well field, covering an area of $0.34 \mathrm{mi}^{2}$. Comparison of the optimized model parameters to an alternate case with increased recharge and hydraulic conductivity values does not indicate a major change in contributing area size (from $0.34 \mathrm{mi}^{2}$ to $0.48 \mathrm{mi}^{2}$ ). However, increasing recharge and hydraulic conductivity appreciably affects the shape of the contributing area.

Data were not available at the scale needed to incorporate anisotropy of aquifers and confining units in the simulations. A detailed aquifer characterization effort for the watershed would be needed to describe and simulate the heterogeneity encountered in the study area. Error in head solutions in model simulations affects the particle-tracking solutions. Reducing uncertainty would improve the accuracy of the particle-tracking solution and, thus, improve the accuracy of the delineation of the contributing area.

\section{Acknowledgments}

The authors thank Larry Campbell, Director of Utilities for the city of Cadillac, for his assistance with data collection and insight on the history of the municipal-well field. Brant Fisher, Wayne Kukuk, Richard Mandle and James Skipper (MDEQ) provided information about requirements for contributing-area delineations, as well as a history of the activities associated with the Cadillac production well field. Eric Chatterson (Roy F. Weston Inc.) provided information regarding water levels and monitoring-well locations for the Cadillac well field. We thank all businesses and homeowners that allowed us to measure water levels in their wells.

\section{References Cited}

Alley, W.M., Reilly, T.E., and Franke, O.L., 1999, Sustainability of ground-water resources: U.S. Geological Survey Circular 1186, 79 p.

Bates, R.L., and Jackson, J.A., 1987, Glossary of geology (3rd ed.): Alexandria, Va., American Geological Institute, $788 \mathrm{p}$.

Calver, Ann, 2001, Riverbed permeabilities; information from pooled data: Ground Water, v. 39, no. 4, p. 546-553.

E.C. Jordan Co., 1986, Work Plan, Cadillac Area Groundwater Contamination, Remedial Investigation/Feasibility Study: Southfield, Michigan, variously paginated.

Environmental Science and Engineering Inc., 1996, Interim response activity work plan Mitchell Corporation of Owosso, Cadillac property: Cadillac, Michigan, variously paginated.

Environmental Science and Engineering Inc., 2000, Annual monitoring report Mitchell Cadillac Facility, July 2000, Cadillac, Michigan: Cadillac, Michigan, variously paginated.

Farrand, W.R., and Bell, D.L., 1982, Quaternary geology of southern Michigan: Ann Arbor, Michigan, Department of Geological Sciences, University of Michigan, scale $1: 500,000$.

Freeze, R.A., and Cherry, J.A., 1979, Groundwater: Englewood Cliffs, New Jersey: Prentice-Hall, Inc., 604 p.

Frier, A.C., 1978, Anticipated effects of municipal sewers on development of Lake Mitchell wetlands: East Lansing, Michigan, Michigan State University, M.S. Thesis, $128 \mathrm{p}$.

Harbaugh, A.W., Banta, E.R., Hill, M.C., and McDonald, M.G., 2000, MODFLOW-2000, the U.S. Geological Survey modular ground-water model user guide to modularization concepts and the ground-water flow process: U.S. Geological Survey Open-File Report 00-92, 121 p.

Hill, M.C., Banta, E.R., Harbaugh, A.W., and Anderman, E.R., 2000, MODFLOW-2000, the U.S. Geological Survey modular ground-water model-user guide to the observation, sensitivity, and parameter-estimation processes and three post-processing programs: U.S. Geological Survey Open-File Report 00-184, 209 p.

Holtschlag, D.J., 1996, A generalized estimate of groundwater-recharge rates in the Lower Peninsula of Michigan: U.S. Geological Survey Open-File Report 96-593, 37 p. 
J. L. Wilcox \& Associates, 1986, Report of Well Performance Test Haring Township Production Well No. 1, Wexford County, Michigan: J. L. Wilcox \& Associates, Inc., variously paginated.

Jones, Henry, and Williams Consulting Engineers, 1959, Cadillac, Michigan: Water Improvements Report: Jones, Henry and Williams Consulting Engineers, variously paginated.

Keck Consulting Services., 1987, Well Field Evaluation: City of Cadillac: Williamston, Michigan, variously paginated.

Legal Information Institute, 2004, Cornell Law School US Code Collection: Title 42, Chapter 6A, Subchapter XII, Part C, Sec. 300h-7: accessed May 4, 2004, at URL http:// www4.law.cornell.edu/uscode/42/300h-7.html .

Leverett, Frank, and Taylor, F.B., 1915, The Pleistocene of Indiana and Michigan and the history of the Great Lakes: U.S. Geological Survey Monograph 53, 529 p.

Martin, H.M., comp., 1955, Map of the surface formations of the southern Peninsula of Michigan: Michigan Geological Survey Publication 49, scale 1:500,000.

Michigan Department of Environmental Quality, 2004, Overview of Michigan's wellhead protection program: accessed April 5, 2004, at URL http://www.deq.state. mi.us/documents/deq-dwrpd-gws-wpu-WHPP-Overview. pdf.

Michigan State University Extension, 2002, Fact book for the development of the Wexford County plan, 2002, Wexford County: Michigan State University Extension, 424 p.

Midwest Climate Center, 2003, Historical Climate Data Available on the Web: Station 201176, Cadillac Mich.: accessed October 30, 2003, at URL http://mcc.sws.uiuc. edu/Precip/MI/201176_psum.html.

Pollock, D.W., 1994, User's guide for MODPATH/MODPATH-PLOT, Version 3: A particle tracking post-processing package for MODFLOW, the U.S. Geological Survey finite-difference ground-water flow model: U.S. Geological Survey Open-File Report 94-464, 236 p.

QST Environmental, 1998, Groundwater model of proposed remedial system Mitchell Corporation of Owosso property, Cadillac, Michigan: Cadillac, Michigan, variously paginated.
Roy F. Weston, Inc. of Michigan, 2001, Technical Memorandum: Review of Project Documents and Groundwater Conditions; Rexair, Inc. site, Cadillac, Michigan: Okemos, Michigan, variously paginated.

Roy F. Weston, Inc. of Michigan, 2002, Additional Hydrogeologic Investigation Report: Northwest of the Rexair, Inc. site, Cadillac Industrial Park, Cadillac, Michigan: Okemos, Michigan, variously paginated.

Stewart, D.P., 1948, The surface geology of Wexford County, Michigan: East Lansing, Michigan, Michigan State College of Agriculture and Applied Science, M.S. Thesis, $32 \mathrm{p}$.

Thomson, F.H., 1969, Hydrology of the glacial section along the Manistee River, Kalkaska, Grand Traverse, Wexford, and Missaukee Counties, Michigan: Houghton, Michigan, Michigan Technological University, M.S. Thesis, 54 p.

Westjohn, D.B., 1989, Application of geophysics in the delineation of the freshwater/saline-water interface in the Michigan Basin, in Swain, L.A., and Johnson , A.I., eds., Regional aquifer systems of the United States, aquifers of the Midwestern area: American Water Resources Association Monograph Series, no. 13, p. 111-133.

Westjohn, D.B., and Weaver, T.L., 1998, Hydrogeologic framework of the Michigan Basin regional aquifer system: U.S. Geological Survey Professional Paper 1418, $47 \mathrm{p}$.

Westjohn, D.B., Weaver, T.L., and Zacharias, K.F., 1994, Hydrogeology of Pleistocene glacial deposits and Jurassic "red beds" in the central lower peninsula of Michigan: U.S. Geological Survey Water-Resources Investigations Report 93-4152, 14 p.

WW Engineering and Science, 1989a, Results of the remedial investigation: Grand Rapids, Michigan, variously paginated.

WW Engineering and Science, 1989b, Aquifer testing: addendum 1 to results of the remedial investigation: Grand Rapids, Michigan, variously paginated.

WW Engineering and Science, 1994, Status report and recommended modifications; ground water and soil remediation system: Grand Rapids, Michigan, variously paginated. 
Prepared by the Michigan District Publications Unit-Sharon Baltusis

For more information concerning the research in this report, contact: Jim Nicholas, District Chief

U.S. Geological Survey

6520 Mercantile Way, Suite 5

Lansing, MI 48911-5991

or visit our Web site at:

http://mi.water.usgs.gov 


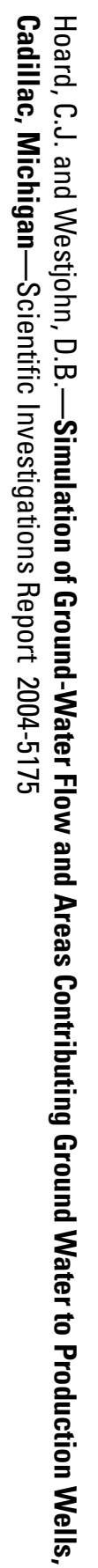

Printed on recycled paper 